\title{
Profiles of Archaeology in the United Science
}

\section{Leif Gren}

\begin{abstract}
This paper aims at a general demarcation of the space of knowledge. A connection is made to the nominalistic philosophical tradition, in which Man is seen as constant and reality as chaotic. Archaeology is regarded as a part of a United Science where knowledge always refers to fictions of Man.
\end{abstract}

Leif Gren, Riksantikvarieämbetet, Fr-sid, Lantmäteriet.

Box 524, S-371 23 Karlskrona. Sweden.

Complicated things are simple. You are looking at the substance of this paper, and when you scratch it, you may hear something. Still you will say it is one and the same paper. In this case sight, sense of perception and hearing give us completely different kinds of knowledge of the same thing.

We live in one world only. The number of sense organs we posses is not equal to the number of worlds we live in. Between the unitary concept and the unitary thing lie the channels of the different senses. Yet without thinking of it, we can combine them into one simple unit of knowledge, thanks to the wonderful skill of our physical constitution. With the use of diverse sciences we can improve the capacity of our senses, thus creating a unified body of scientific knowledge.

Man has always been more or less interested in what precedes this very moment, simply because he has some use of this knowledge. How far back before this very moment or individual experience this interest is projected varies a great deal. Frequently the most shallow references to the past have been sufficient, but gradually demands for a more and more critical history and archaeology have been raised. It is not unusual for archaeologists to discuss methods for where and how archaeology ought to be practised. In this paper, however, we are going to discuss why archaeology exists, and especially how archaeology is possible at all. In order to do this we have to figuratively penetrate the depths of the cellar in the huge building of the scientific archaeology, and look below everything that is called the empirical source material and below all the complex and beautiful theories about ancient societies.

In an everyday sense one must, for practical reasons, have some concepts of the past. However, most of the knowledge of the ancient past could hardly be described as necessary for living. Within the science of history attempts were made for many generations to illustrate different things such as Hesiodos' five ages of the world, Augustinus' drama of world history or Hegel's perfection of the world spirit. The science of history took a long time to attain Ranke's simple search for facts and "how things really were". Since Ranke things have become more complicated again with Dilthey's understanding, de Saussure's structures and Malinowski's functions. However, we do not need a more complicated history any more than we need to make a tool more intricate than necessary. We need a path back to the simple and practical way of looking at the past.

We often talk of different kinds of archaeology. We ought more often still to discuss only one kind of archaeology. Ultimately all archaeology must have something in common, otherwise it would be impossible to imagine different perspectives. In this context we will analyse what unites all archaeology, it 
being first necessary to give a general answer to the questions of the objectives of archaeology and what archaeological knowledge, its starting-point and the archaeological context are.

The most appropriate way of understanding archaeology is to define knowledge as such and how different kinds of knowledge are united. It may be argued that this is not a matter of archaeology, but this would be a category mistake according to Gilbert Ryle's concepts. The significance of such mistakes is illustrated by one of Ryle's examples (1949:17): "A foreigner visiting Oxford or Cambridge for the first time is shown a number of colleges, libraries, playing fields, museums, scientific departments and administrative offices. He then asks 'But where is the University?","

In the same way as diverse institutes join together to form a university, different sciences are united in a total science. Specialised sciences can be sorted into general categories. Mathematics and logics, for instance, are general sciences that must be applied uniformly in other sciences - archaeology does not use its own multiplication table, does it? If we want to understand archaeology we must acquire a general view. We do not have archaeology and comprehensive science, but archaeology as part of comprehensive science.

\section{WHAT IS SCIENCE?}

Archaeology is a science, we say. It may be asked what separates sciences from other kinds of human products, i.e. what is the general criterion of demarcation for all sciences? The starting-point here is that science is the production of general knowledge, the result according to defined prerequisites being the very same regardless of who produced it. This is a decisive difference compared to aesthetics, where the result is always dependent on the practicioner. Thus archaeology as a science can never be an aesthetic phenomenon. The difference seems clear in Nietzsche's definition: "Ultimately, man finds in things nothing but what he himself has imported in them: finding is called science, the importing - art, religion, love, pride" (1901:327).

A consequence of this reasoning is that there can never be any firm boundary between sciences and everyday knowledge. As Nietzsche puts it, one cannot separate theory from practice and live with "two different standards" (1901:253).

For instance, if one says "It is sunny weather today", is that a scientific statement, or is it just simple everyday knowledge? Naturally there is no contradiction, since we first must have implied conventions for what we in an everyday sense mean by sunniness. Willard van Orman Quine remarks that: "Science is a continuation of common sense, and it continues the common-sense expedient of swelling ontology to simplify theory" (1955:45). Science is always preceded by everyday knowledge.

The only way of separating everyday knowledge from science is to construct clearer and more well defined conventions for our intentions. If one, for instance, says that "there is more ultra-violet radiation in the sunshine today than ten years ago", then it is a scientific expression if a conventional definition of ultra-violet radiation is given. There is of course no everyday implicitly understood convention of what this radiation is. Thus, in science one is forced into new definitions, and these must of necessity be assigned to everyday knowledge. In the example above the definition of ultra-violet radiation may be that it is the kind of light that is closest to violet when purely white light penetrates a prism. In this case all the components of the definition are reduced to everyday knowledge, provided that one knows what a prism is. If this is not known, the definition has to be further reduced, or, as Nietzsche puts it: "Something strange is to be reduced to something familiar" (1882:300). Scientific knowledge must always be reduced to everyday knowledge if it is to be of any use.

A definition is certainly better if it can be assigned to perception of the senses rather than complex concepts. However, the statement that scientific definitions must of neces- 
sity be based on everyday senses naturally does not mean that these definitions represent any sort of "truth in themselves". They are a kind of "truth" due to a common convention that is based on "built-in" conventions in our sense organs. When we, for instance, see"something" this something is always characterised by boundaries or outlines that are our "natural conventions" of seeing. An outline is of course a mere fiction of no real existence. All knowledge, both everyday and scientific, can be traced back to conventions, that in their turn rely on the fictions of the sense organs.

David Hume says that we can never transcend ourselves, and that we cannot possibly obtain any concept of what is outside the "universe of our own fantasy" (1738:92). Our sense organs can never give us any impression unless they rely on boundaries. In reality there are no boundaries "as such" whatsoever; they are all attributed and fictive, or as Nietzsche puts it, "We operate only with things that do not exist: lines, planes, bodies, atoms, divisible time spans, divisible spaces" (1887:172). The foundation of knowledge is the boundary.

We project fictions upon reality in the same way as we use a key in a lock. If the key works we do not have to bother about the construction of the lock. If the key does not work we ought to find a better key rather than cursing the lock. However, as long as our fictions are common property, it is not necessary to take into consideration that they do not exist in reality. In most everyday descriptions of physical reality the question of who is doing the describing is of no operative significance. Thus, in a practical sense it can be said that most everyday knowledge is fully scientific. Quine is right that we ought to look at things in a pragmatic way (1955:44).

One characteristic of science is that it claims to be useful in some sense. Ultimately science does not aim at creating more and more knowledge or greater understanding. As the founder of positivism, Auguste Comte, asserts, the intention is to create greater possibilities. If some branch of science proves to be of no use, regardless of how long it is practised, then it must be characterised as an aesthetic phenomenon. The question is how science can be used.

We may refer to the eighteenth century philosopher Etienne Bonnot Condillac's famous example of a statue that gradually becomes conscious, the sense organs becoming more and more active. We may turn the reasoning upside down and say that as the statue obtains one sense organ after the other, it becomes capable of attributing boundaries in reality. When no sense organs are present, the statue is "living" in chaos, and it cannot separate time from space, earth from wind, fire from water. It would perish without even noticing the fact. However, with one sense organ after the other it can separate its impressions by fictive boundaries, being thus given the opportunity to avoid or alternatively utilise them. Science is the same as the striving of man to delimit operative effects in the most powerful manner.

The goal of all knowledge and every science is to delimit effects in specified problems. In this context the concept of effect equals the concept of cause-to-change. Cause and effect are two sides of the same fictive thing. Hans Vaihinger says that we have to create order out of disorder, and that our consciousness chooses certain things from the chaos of sensations: "We do not think that our mind should have any reason to do this except by a practical necessity. On the contrary we believe that it was only need in the widest sense that drove ahead the disposition from the mind, to out of this perpetual connection of impressions make a certain category" (1918:298; my translation). If one cannot delimit a cause in a composite process or event, it seems completely chaotic and incomprehensible, both in an everyday and scientific sense. Chaos is a mirror of bad analysis. Science strives to reduce the accidental into calculable constants.

For instance, if one falls ill, the problem may be identified as the lack of a certain vitamin. If a bridge has been built and it collapses, the error may in a similar manner 
be pinpointed as the inability of the concrete to withstand vibrations. In other words, a composite totality exists and from this we single out a particular circumstance. When it is clear that effects have been delimited as far as possible, useful and applicable knowledge has been gained and can be used to control the effects. The objective of all science is to delimit operative effects.

As Ralph Waldo Emerson reminds us, we never create effects, we only delimit them and place our efforts under their control, "That is the way we are strong, by borrowing the mights of the elements" (Works, vol. 7:32). To what extent it is possible to delimit effects in this manner depends both on the potential of the science and on what is deemed necessary. In the first case a certain effect seems consistent and it is not possible to make any further dissections. In the latter case the delimited effect is sufficient to permit action. The production of knowledge follows this pattern: the chaos of yesterday becomes the science of today and this in its turn becomes the everyday knowledge of tomorrow.

\section{WHY ARCHAEOLOGY?}

Life is a perpetual falling. In the evening we fall into bed, and then we fall asleep. In the morning we fall out of bed, towards the breakfast table, towards our place of work, towards what we like, away from what we disapprove of, etc. We may try to stop this, but we can only delay the process for a while; then it restarts or does it?

When the process of falling cannot be stopped, we call it necessity, and when it seems possible to stop it, we call it freedom. We are driven to our fall in two ways - by our body and by the things in our environment. Our body makes us fall because of what we suppose to be our natural disposition, and the things in our environment by extending our mental and physical capacity. The only way to judge whether our fall constitutes necessity or freedom is to look backwards into experience, into history and archaeology.
Emerson is right when he states that the task of history is to lend importance to the present moment. Reverence for our forefathers is a treacherous sentiment, since "Their merits were not to reverence the old, but to honor the present moment (Works, vol.7:170). We have to explain more precisely what we mean by knowledge about the past. Knowledge consists of referring to effects, and the kind of effects scientific archaeology is to delimit must be defined. The identification of effects always goes back to experienced problems that are more or less implicit. That we love, we do not analyse, but that which is uncomfortable, we analyse into atoms.

Science is meant to produce facts or knowledge. That scientific archaeology is intended to produce knowledge about ancient times lies in the concept itself. Science should not, of course, produce just any knowledge about any origin. Nietzsche stresses (1881:31) that the more insight about an origin we arrive at, the less important the origin itself seems, "The founder -of a religion can be insignificant - a match, no more!". If we, as Thomas Aquinas, were to look for the "primus motor", the cause of everything, then history would be just an illustration of what we thought we already knew.

As far as archaeology and history are concerned, it is not the imagination of the past, but rather the future, that justifies science. Our thoughts belong of necessity to the vanishing moment we call the present. Then we have to split time into the past, the present and the future.

When we see how something is we can imagine how it will be. When we are faced with a potential problem, we are inclined to look into the past to see how it used to be. Consequently, archaeology and history are occupied with how something is by "nature", i.e. ontology. To define how something is corresponds to saying how it ought to be, and that is a moralistic statement. Science is moralistic. Nietzsche emphasises (1874:94) that in order to understand history, one has to be an "architect of the future". 
In principle archaeology and history should not try to show "what happened in history", "how things were" or "what the purpose was". Ultimately an attempt should be made to reveal the nature of experienced problems. Put in another way, the scientific study of the past should always include some kind of usefulness. It may be thought unreasonable to demand usefulness of the human sciences, but if we want the scientific aspect of the humanities to prevail, then we have to consider their use, otherwise they will dissolve into pure aesthetics.

The question of the use of archaeology will perhaps become clearer, if we imagine an absurd situation whereby archaeology as we know it today were wiped out and replaced by the seventeenth century Old Testament version of history. Archaeology is a question of ontology and allusion to the future.

\section{WHAT IS THE UNITY OF SCIENCE?}

At least since the three-period system was introduced into archaeology a century and a half ago, archaeology has been divided up into different branches such as Stone Age, Bronze Age and Iron Age archaeology. More recently archaeology has been split up on the basis of art, typological elements, settlement, economy and ecology. Moreover, in different interpretative models functions, structures, systems, etc have been stressed. Which of all these perspectives should one choose then? The answer, as Mats P. Malmer maintains, is of course, that we want to know everything of significance (Malmer 1984:267). Consequently all perspectives that are scientifically sound can be chosen, i.e. the perspectives that can be shown not to be pure aesthetics.

Functions, structures and systems are the extended sense organs of the science, its eyes, ears and sense of perception. A critical scientist tries to use all sense organs. It would be a category mistake to exclude aspects of function in an analysis of structure. The great rationalist, Gottfried Wilhelm Leibniz, is right when he says that though a town viewed from different directions seems "perspectively manifold", it is still one and the same town. Correspondingly there is only one world system, even though there are an infinite number of perspectives of the world (1714:156f).

If all knowledge was not unified by some specific aspects, it would not be possible to recognise different perspectives. The very concept "perspective" presupposes one central object. There is in essence only one science of archaeology (Malmer 1991:286), and there is only one united science.

Within the Platonic and Aristotelian traditions during classical antiquity and the medieval period it was self-evident that all knowledge relied on the very same premisses. Unfortunately this holistic view has to a great extent vanished. In the wake of the seventeenth century scientific revolution there has been a tendency to set up a boundary between different kinds of sciences, especially the human and natural sciences. During the nineteenth century many scientists, such as the humanist Dilthey, caused a lot of confusion by saying that the human and natural sciences were incommensurable.

In contrast to this dualism, so-called "positivism" has rightly stated that all sciences refer to the same prerequisite, and that they are united in a general science. Fundamentally there cannot be any boundary, for instance between "natural and psychological sciences. This is the thesis of the unity of science" (Carnap 1937; quot. after Jones 1975:320). Let us re-establish the idea of the united science of classical antiquity.

In this context prominence must be given to the fact that it is only the ideal that should be re-established. It would be a mistake to believe that the unity of science is something that is missing. Science has always been united, just because our sense organs always have been so. This point simply has to be emphasised. 


\section{HOW CAN WE FIND A FIXED STARTING-POINT?}

In general, knowledge could be said to be equal to a set of explanations and insights referring to what seems obvious. "'Knowledge' is a referring back: in its essence a regressus in infinitum" (Nietzsche 1901:309). However, is there anything that cannot be subjected to further analysis? Logically there should be something that is the utmost starting-point for all explanation and understanding in the same way as the point of Archimedes is a prerequisite for the movement of the Earth. In principle this is the same problem as that expressed by Descartes in his famous doubt: "I decided to suppose that nothing was exactly as our senses would have us to imagine... I resolved to pretend that everything that had entered in my mind was no more true than the illusions of my dreams" (1637:17).

The fixed starting-point must be something that is valid regardless of time and space. Within archaeology it has been tacitly accepted that the empirical material is the fixed starting-point. However, we know perfectly well that the perception of objects is culture-related and that it varies. It is the same with "society", "culture", "environment" and "laws of nature". In short, the perceived is always variable, and we must share the scepticism of Hume as far as the means of finding an absolutely firm and safe starting-point are concerned. If we cannot find the startingpoint in the objective, then let us turn, as Sören Kierkegaard says, to the subjective, that is, perception.

Subjective perception is a linguistic phenomenon, and it is in language we should search for our fixed starting-point. This conclusion has been drawn by all philosophy of importance in the last two hundred years. In order to understand and explain something in reality we have, of course, to use concepts and language. It must be underlined that language in this context includes not only speech but all perception of the senses. In other words, language as it is used here, is synonymous with the concept of cognition. The question is how the connexion between concepts and reality comes into existence. This is a very typically philosophical question, and we ought to consider different ways of solving it. The philosophers have confused us, and they have to deconfuse us.

Plato's well-known thought is that the world of ideas has to be separated from the world of phenomena. The world of ideas, he says, is the cause of things; it is an unchangeable, objective and independent reality. The world of phenomena, in which we obtain our experiences, is real only in as far as it is a part of the world of ideas. Reality is a reflection of the world of ideas, and real knowledge, that is the starting-point, is attained or divined by philosophical insight or mathematics. Plato's path to knowledge can be described as completely extra-human since the real is independent of man and beyond the empirical world. In this way science becomes anti-empirical.

Pythagoras is less inclined to separate concepts from things. The fixed starting-point consists of numbers, and everything can be reduced to and comprehended by means of numbers. This is particularly apparent, says Pythagoras, in the regular scales of music. Everything, including social relationships, can be reduced to numbers.

In parallel with Pythagoras, Aristotle locates the origin of concepts in the thing, but he abandons the teaching of numbers. Instead, Aristotle interprets things as composed of the qualities of form and matter. Things can be related according to what proportions of form and matter they comprise. The more form in a thing, the more complete it is. Unlike Plato, Aristotle is of the opinion that the fixed starting-point can be found in the thing. Aristotle's path to knowledge can be described as semi-human. Man creates forms but forms are also independent realities.

Herakleitus dismisses the idea that the concept is located either in a distant world of ideas or in the thing itself. Everything is in flux, and the only consistency, except for the 


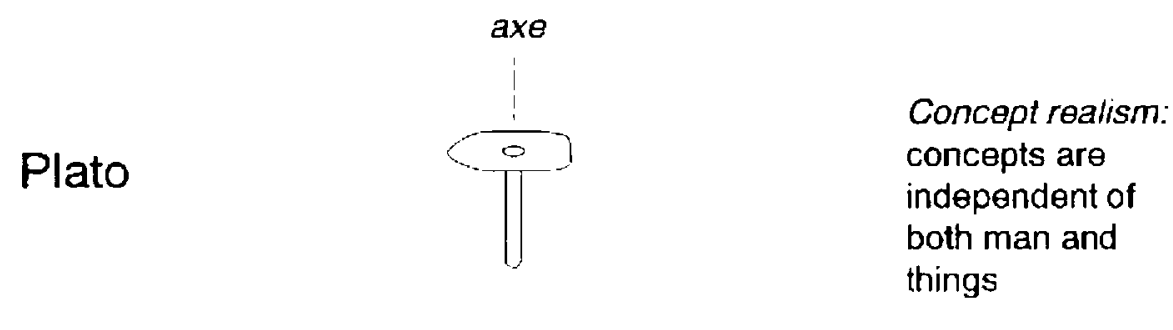

\section{Pythagoras Aristotle}

\section{Herakleitus Antisthenes}

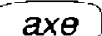

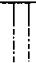

Concept realism: concepts are in the form of things

Nominalism: concepts are in language

Fig. 1. What is the relationship between things and concepts?

flux itself, is thought. In the thing there are no concepts that can be used as a starting-point; this can only be found in our own thoughts. Herakleitus' path to knowledge is entirely intra-human in the sense that reality is bound up with man and his language. A similar view is held by Antisthenes, who maintains that truth is to be found within language only.

The different views of Plato, Pythagoras and Aristotle are usually characterised as concept realism, as concepts are interpreted as an independent and real mode of existence. The view advanced by Herakleitus and Antisthenes is called nominalism, meaning that concepts are found within language (nomen $=$ name). The relationship between the two different kinds of philosophy runs through the whole of western history as a continuous thread. The question is still of utmost importance, even though nominalism has been predominant for the last two centuries. Influential variants of nominalism in modern times are fictionalism and the philosophy of language.

The western concept-realist and nominalist traditions can be summarised in the follow-

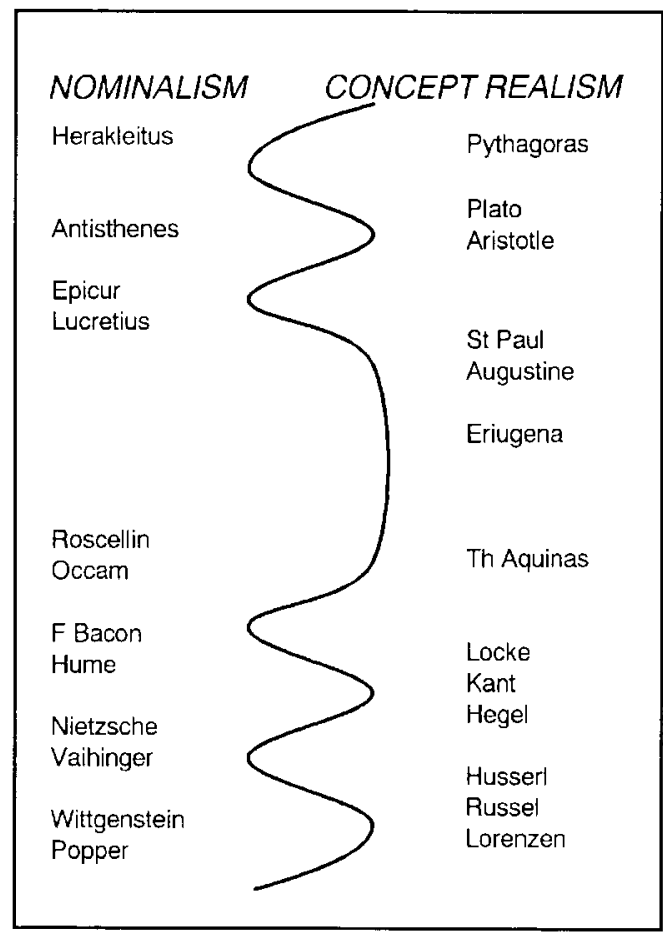

Fig. 2. The different views of nominalism and concept realism run through the history of philosophy like a continous thread. 
ing way. The concept-realist sees man as chaotic and reality as constant, whereas the nominalist regards man as constant and reality as chaotic.

\section{HOW CAN LANGUAGE ESTABLISH} A FIXED STARTING-POINT?

Philosophy is never wrong, but it certainly can be put in the wrong position. Man cannot think incorrectly, because this faculty was wiped out by natural selection some hundred million years ago.

In my view nominalism should act as the starting-point. However, we have to define more exactly which parts of language can be considered constant and selected as fundamental concepts or principles. Man has always utilised fundamental concepts in diverse connexions. Colours, for instance, can be regarded as fundamental concepts of visual things. Concepts of colours can be read into everything. Correspondingly, length, width and height can be considered as fundamental concepts in spatial terms (cf. Malmer 1968). What are the fundamental concepts or principles of cognition then?

When Plato, for instance, refers to the "world of ideas" and the "world of experience" both these concepts can be called his fundamental concepts of reality. In the same way it can be stated that Immanuel Kant's fundamental concepts are "time" and "space". Martin Heidegger alters this, preferring the concepts of "being" and "time". Jean-Paul Sartre reinterprets the fundamental concepts as "being" and "nothingness".

If we in this connexion are going to select fundamental concepts according to language, the concepts must be referred to logic. Boundaries of some kind are a prerequisite for language. Man constructs fictive boundaries where no real ones exist; in other words he makes the variable constant. We can draw a fundamental parallel with Herakleitus.

As W.H.S. Jones states (1931:453), change is a basic theme in Herakleitus' works: "There is no pause in change; it is as much a contin- uum as is time". One of Herakleitus' famous expressions of this is "Into the same rivers we step and do not step; we are and we are not" (fragment 81). From the following statement we understand that it is man who fills reality with significance: "Man, like a light in the night, is kindled and put out" (fragment 77). The collective qualities of language are underlined in the following: "Thought is common to all. Men must speak with understanding and hold fast to what is common to all..." (fragment 91).

If we are going to focus on fundamental concepts, we can expect a totality or a concept to be broken down into its component parts. This relationship can be illustrated by one of Blaise Pascal's metaphors:

"Distinction. The theology is a science, but coincidentally, how many different sciences does it not include? A man is a homogeneous substance, but if we dissect him, it will be shown that he consists of head, heart, stomach, circulation of the blood, blood-vessels, smallest part of bloodvessels, smallest drop of blood.

A town and a countryside in a distance is a town and a countryside. But if we get closer they become houses, trees, bricks, leaves, plants, ants, ants' legs, etc ad infinitum. Yet, all this is included in the concept countryside" (1669, paragraph 113; my translation).

Pascal does not elaborate on the relationship between totalities and parts, but from it there follow two fundamental concepts - continuum and boundary. Leibniz (1695) speaks of these concepts, and maintains, as does Herakleitus, that reality is a continuum. This argument is clearly developed by Hume (1738), who says that, in contrast to our "ideas" which are always delimited, time and space are infinitely divisible. We must reject the idea that the capacity of our reason is infinite, and hence realise that there must be a boundary between reason and ideas. This conclusion, says Hume, is inexorably convincing. 
In Kant's and Hegel's days philosophers were inclined to create such large philosophical systems that they could not keep them together themselves. However, if a logical system of reality as a continuum is created, the risk of moving further and further away from reality increases as the number of boundaries rises. If it is desirable to restrict the number of "extra" boundaries to the absolute minimum, at least the concept of boundary itself has to be retained. On this basis, any philosophical system must lack correspondence with reality, and a philosophical system can never become more "real" by becoming larger or more advanced. As soon as we say that "something exists" or that "something is done" we have left reality in "itself", since we then, as Nietzsche claims, have separated the thing from its existence, and the thing from its action.

A fixed starting-point can be considered as a kind of law, and Montaigne says that "The most desirable laws are those that are the fewest, simplest, and most general" (1580, book 3, ch.13). In this connexion we can be fully content with a philosophical system and a fixed starting-point consisting of only two concepts. The two concepts that we derive from Herakleitus are the very essence of logic and the essential prerequisite for all classification and thinking; continuum and boundary - the total philosophy.

When we use one and the same concept in two different connexions, we are making a mistake since identity does not exist. Now we can, as Montaigne maintains, successfully use identities with various degrees of similarity, "If our faces were not similar, we could not distinguish a man from a beast; if they were not dissimilar, we could not distinguish one man from another" (1580, book 3 , ch.13). If we use the concept of continuum in a similar way, we can cover absolutely everything that man can delimit.

From the fundamental concepts follows the most essential structure of logic. When drawing a boundary in a continuum we are bound to obtain a hierarchical structure, though in practical life we always use a huge number of intertwining hierarchies. This may seem too complex and impossible, but, as Maurice Merleau-Ponty maintains, "nobody knows better than we do how this miracle is worked, for we are ourselves this network of relationships (1945:XX).

Just as we grow from the impregnated primitive cell, our thoughts grow from a fictitious primitive continuum. Emerson rightly says (Works, vol. 4:34) that the act of dividing large and small is general, not only in nature, but also within the spheres of thought and society. Arthur Koestler (1978, ch.1) uses the term "holon" for a part in a hierarchical structure, and justly notes that, like the mythological Janus, such a holon has two faces, one referring to its dependency within the structure and one on its independence as a part.

What do we gain from this? History and everything human is composed of actions, and the prerequisite for actions is cognition and a language. Karl-Otto Apel maintains that "my cognition is my world". From a scientific point of view the conclusion which can be drawn from this is absolutely necessary if history is to be understood. Every human act is performed and every human product is made in a consistently logical way.

Since the fundamental concepts can be imported in any cognitive connexion, it is clear that cognition is logically constructed. Alfred Ayer of course very rightly promotes the idea that our empirical knowledge cannot possibly rest on a basis of logical certainty (1936:160). However, the allusion here is not to reality but to man's apprehension of reality. Thus the fundamental concepts comprise the fixed starting-point, and this is the only thing we can be convinced about. Montaigne is right in his dogmatic statement: "Assertion and dogmatism are positive signs of stupidity" (1580, book 3, ch.13).

It may be objected that general statements about how human thinking works are very unsure. We know ourselves rather well, but how can we deal with the thinking of people in foreign cultures, that of ancient people and, in 
particular, that of pre-humans. However, this does not change anything, since the fundamental concepts are general in absolutely any cognitive connexion. We cannot separate thought from cognitive language, since thought is language. We cannot separate action from thought, since action is performed through language. John Langshaw Austin rightly reminds us that "to say something is to do something" (1955:12). Cognition is equal to recognition and separation, that is to setting up boundaries. This is a distinctive feature of all humans, all animals including amoebas and even electronic computers. In this light there can, according to the definition, be no such thing as human "irrationality". Man is doomed to be rational.

If our fixed starting-point is to be general, it must be applicable to any human context, but the greatest critic of logical systems, Sören Kierkegaard, maintains that "System and finality are pretty much one and the same, so much so that if the system is not finished, there is no system" (1846:98). Kierkegaard's conclusion is that a logical system is possible, but that an existential system is impossible. The latter, he says, is not possible since it cannot be described in words, even if it does exist, "Reality itself is a system - for God; but it cannot be a system for any existing spirit" (1846:107).

Together with Emerson we can agree with Kierkegaard's first statement, "A man is a god in ruins" (Works, vol.1:74). And along with Nietzsche we can agree with the second statement, "There exists neither 'spirit', nor reason, nor thinking, nor consciousness, nor soul, nor will, nor truth; all are fictions that are of no use" (1901:266). When Kierkegaard further says that "Existence separates, and holds the various moments of existence discretely apart; the systematic thought consists of the finality which brings them together"' (1846:107), he gives prominence to the fundamental concepts of continuum and boundary. Thus existential systems are also possible.

That which we have pointed out as a linguistic, fixed starting-point is the structure of all language, i.e. of all cognition. The content, however, is variable. Thus the fundamental structure of logic is a "hierarchical chain" that is identical in every conceptual connexion. In such a hierarchical chain of boundaries there must be two further constants apart from the structure itself. There must be the greatest and most general unit or a primitive continuum. There must also be a smallest and a least general unit.

Man is a generous metaphysician. The chain of concepts must be delimited, and thus very general concepts evolve spontaneously, such as "Cosmos", "God", "Chaos" etc, and particular concepts for "I", "individuals", "atoms", etc. We cannot avoid such a conclusion, but we can of course choose the concepts we prefer, or more accurately, those we think are practical. What we need most of all are collective human concepts.

The concept logic may here be defined as boundaries drawn and bound within a consistent structure, with no reference of any kind of "good" or "bad". Even if the platonist Leibniz relates to independent boundaries outside man, we can agree in his optimism when he vindicates that reality is characterized of the logical, in the sense above, and that the most remote and hidden things can be explained by analogy and what is within our proximity (Leibniz 1705:126).

Many people, of course, have objected to this argument. Kierkegaard has already maintained that we have to look more closely at the subjective side of man. Man is characterised not only by reason but also by feelings and playfulness. If the last two qualities are irrational, we would have no use of fundamental concepts. Henri Bergson puts forth that we must consider some kind of "elan vital", or life spirit. And some philosophers, such as Bernhard of Clairvaux, are very sceptical of rational reasoning, asserting that we must separate reason from emotional feelings. To counter Bernhard's objection we have to consider the nature of feelings.

Let us hold our breath! The resulting sensation becomes stronger and stronger until it 
would make an impression even on Bernhard. How are we understand this? Intentionally we act in one way; that is we use one kind of logic. Then our body reacts unconsciously due to another kind of logic, that is the inborn physiological "logic". Our will goes in one direction, and bodily reflexes in another.

As Nietzsche maintains, one dominating feeling can be split into several different parts: "The antagonism of the passions; two, three, a multiplicity of 'souls in the breast': very unhealthy, inner ruin, disintegration, betraying and increasing and inner conflict and anarchism - unless one passion at last becomes master. Return to health" (1901:408). Thus feelings are the product of at least two intertwined but competitive kinds of logic. To use a metaphor, we can say that we have different "poles" of logic, or in Freudian terms, logic that is conscious, subconscious, unconscious and physiological. Between the poles of logic there are strokes of lightnings that consist of emotions.

Feelings are direct stimuli caused by independent "poles" in the sense-organs. Emotional feelings are indirect stimuli caused by independent "mental poles". Ryle points out that we can compare feelings with bodily sensations, and if feelings were incomprehen- sible "not only would people be absolute mysteries to one another, they would also be absolutely intractable. In fact they are relatively tractable and easy to understand" (1949:110).

Neither can play be separated from reason and calculation. On the contrary, Johan Huizinga says that it is play more than anything that creates order and logic. Play demands unconditional order, and the least deviation from the rule spoils the game and makes it pointless (1945:19). The desire for order, says Huizinga, is characteristic of all culture. Culture does not start as play, and it does not emerge out of play, but it starts in play (Huizinga 1945:86).

There is no fixed starting-point beyond the distant, neither is there any too close in the proximate. In this connexion we have tried to eliminate scientifically unquantifiable feeling by reducing all human cognition and activity to some kind of logic, but do not feelings lie at the bottom of these efforts!

\section{WHAT CAN WE KNOW?}

When we say that we want to acquire all archaeological knowledge, we must mean that we want to know everything that can be di-

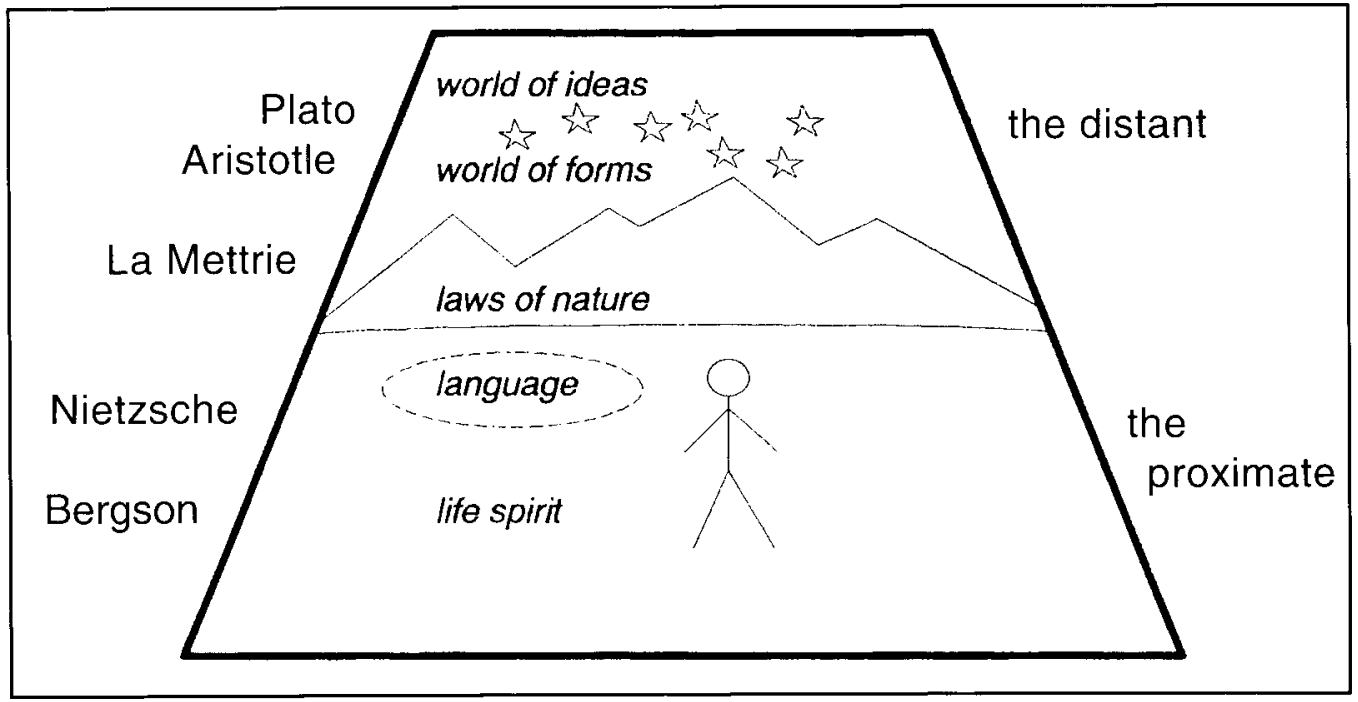

Fig. 3. Where is the fixed starting-point - in the distan or in the proximate? 
rectly or indirectly inferred about the intentions of ancient people. In this case we must, as has previously been maintained in this paper, reject all knowledge that is not created by or attributed to man. Kant set up a boundary between two kinds of truth, constructed analytical truth and synthetic truth based on facts, but as Quine maintains (1955:20ff), such boundaries are artificial, since there are no independent facts. Thus, all facts are dependent on man, and consequently they can in principle always be attained. In Herakleitus' sense, human intentions are the light, and reality is the darkness - let us behold the light. In this question we can adopt the position of optimistic rationalism.

Descartes says that it is possible to base a science on a fixed starting-point without committing "the error logicians call a vicious circle" (1637:40). Well, does not the reasoning above rest on such a vicious circle? Must there not be something "outside" the fundamental concepts, in Herakleitus' darkness, something that cannot be described in terms of logic? Yes, surely! This is probably about as sure as the fact that our reasoning so far really is a vicious circle, but it does not change anything, since it is of no operative importance whatsoever.

Paul Ricoeur claims that "we have experience to bring to language" (1976:21), but this is not a clear statement. Experience is not possible without cognition, and cognition always involves boundaries. Consequently cognition is equal to language which in its turn is equal to experience.

Human cognition is a vicious circle from the beginning to the end. As Nietzsche asserts (1886:23), we cannot even take for granted the famous Cartesian "I think" without referring to other concepts. It is of no importance that cognition is sentenced to exist in a vicious circle, since everything that is of significance to us is within this circle. Leibniz said that we live in the best of worlds, but he could just as well have said that we live in the only world that concerns us.

We may use a parable from mathematics, and say that we cancel an unknown factor on both sides of the equals sign. The unknown factor we want to get rid of is of course the classical "extrahuman" that Kant, for instance, called the "thing in itself". Here we can call the extrahuman factor the "alogical". The cognition of one individual, as Herakleitus might have said, cannot evolve into a complex language without participation in a collective community of language. In other words, the language of one individual is related to the alogical continuum of reality in the same way as that of another individual. Correspondingly, our language relates to the alogical continuum of reality in the same way as that of ancient people did. Now we simply have to cancel that unknown "alogical", and thus it is of no operative importance.

We can say that the alogical is eliminated by an act of "operative equivalence". In this manner we can be certain that all language is "logically equivalent"; this is an absolutely necessary prerequisite for all knowledge. Is that all?

Not exactly; this reasoning is valid only on the assumption that the alogical above can be held constant. How is such certitude possible? It is not! Natural scientists have always tended to claim that the "laws of nature" are constant, but better "evidence" is provided by what Karl-Otto Apel calls the growing community of language, i.e. the fact that we understand each other at all over time and space. Since the "alogical" is not relevant, we may adopt the position that Nicolai Hartmann calls a "gnoseological monism". The meaning of this is that everything is connected, and that there are no boundaries in reality. That is all.

The concept of "operative equivalence" is something that we have always used and still have to use. This is exactly what we do when we attribute similarities and identities. We use the same word in different connexions. Thus, as Nietzsche claims (1901:273), every word is a prejudice and a "Procrustes bed". For instance, when we say that two things are equal, we refer only to the part of these things that is of operative importance for us, e.g. 
size, form, material, etc. The fact that two different but similar objects can never be constituted of the very same material is seldom of any operative importance to us. Further we can say that a model of a certain thing is "exactly the same" even though it does not share any physical similarity. Of course this may be completely irrelevant if we assign operative importance only to some defined properties. As Leibniz correctly maintains, two objects can be considered identical as long as the truth is not changed.

We have come to the conclusion that there is nothing "outside" our language, i.e. cognition. But is there nothing to consider "inside" that we can reach by cognition, "at the bottom of our soul"? No. There are no "inner facts" that are not fictively projected (Nietzsche 1889:58f.). And as Merleau-Ponty points out, "there is no inner man, man is in the world, and only in the world does he know himself" (1945:xi). There is nothing beyond the cognition of man.

\section{WHAT IS THE FOUNDATION OF THE HUMAN CONNEXION?}

Science is the tool that gives us power to see and draw boundaries where none can be seen with the naked eye. However, archaeological science must of necessity have a medium to look through; this is what we call archaeological empirical source material. Yes, at last, exclaim the archaeologists; we long for the empirical facts!

Empirical facts are measurable theory. The empirical facts of today are the theory of yesterday. The good theory of today might evolve into the empirical facts of tomorrow. How do we find an empirical base of this kind?

In the last few decades an archaeological connexion has usually been created with the aid of different kinds of systems theory. A common general view within systems theory is that there are fixed starting-points in nature. Systems theory is primarily inspired by the natural sciences, and presumes that the "laws of nature" are valid throughout time and space. From a pragmatic point of view it can be said that the laws of nature can be considered as constant, but even if this is so, they cannot be used as independent archaeological empirical facts.

The mistakes of materialistic systems theory are manifold. Systems such as relationships between species and ecosystems are regarded as natural and existing "in themselves". Of course such ideas are projected fictions. Nature is a continuum but man is a boundary. Man has often been separated from nature, but nature is everything. Nietzsche maintains that "We speak of nature and forget to include ourselves: we ourselves are nature" (1886b:390). Consequently man in "himself" is also a continuum. Reality is not static but dynamically changeable. As Nietzsche claims, we should search for the constant in man.

"In regard to everything external to us no conclusion can be drawn that something will be thus or thus, must happen thus or thus; it is we who are more or less secure and calculable; man is the rule, nature is irregularity" (1886b:63).

The most fundamental mistake of modern systems theorists is that they have not grown out of idealism in the form of - materialism! Systems theory has frozen into static materialism. Materialism and idealism are two sides of the same counterfeit coin. In the nineteenth century idealism was still seen in opposition to materialism (Lange 1865). Classic materialism, however, speaking of such things as "substances" and "atoms" as independent realities, is really no more than just a variant of Plato's ideas. The only difference is that materialism seems to have moved Plato's extrahuman boundaries closer to the world of sensations. As Nietzsche asserts, we always tend to search for fixed boundaries in the form of constant causes in reality, and "because we find no such constant causes in actuality, we invent them for ourselves - the atoms" $(1900: 334)$. Thus it is man that invests reality 
with meaning, and it is in the language of man, rather than in nature or matter, that we should search for our fixed starting-point. The Roman philosopher, Manilius, expresses this clearly: "Do not search for the limits of matter. Search instead for the power of reason not matter. Reason is the master".

We are so proud of the bourgeois invention that we call individualism that we forget how fundamentally collective reason is. Our language, i.e. our cognition, would not be possible without the collective community of language that has evolved over a long period of time. In this connexion a "long period of time" amounts to one or two billion years. In a practical sense it is, for instance, so effective to have concepts for "things" and "matter" that evolution would not admit us to survive without them. The concept of truth often confuses those of us who live in the midst of the collective. The first person to find a "truth" that in principle is collective is called a genius; the last person is called an idiot.

One might say that the most useful concepts can be called archetypes. Archetypes have no existence of their own, of course, but they are recreated in every human being. The words of the archetypes vary but the boundaries are the same. The effects of nature are understood in the same way by the sense organs, but they must be expressed as a metaphor, i.e. a word. Emerson says that "Language is fossil poetry" (Works, vol. 3:26) and that "The world is emblematic. Parts of speech are metaphors, because the whole of nature is a metaphor of the human mind" (Works, vol. $1: 38)$.

Nothing evolves out of nothing, and everything in the human sphere refers to the past. Emerson uses a metaphor; everything said or written is a quotation and every house is a quotation from all forests, mines and stone quarries, and "every man is a quotation from all his ancestors" (Works, vol.4:44).

As Karl-Otto Apel maintains, some general concepts are continuously being added to language, consequently increasing the community of language. With the aid of language we carry both ancient and living collective experience in our heads. We can think individually by combining the words, and we can derive new words, but we cannot possibly think one single thought without utilising a collective language in its broad sense. This is

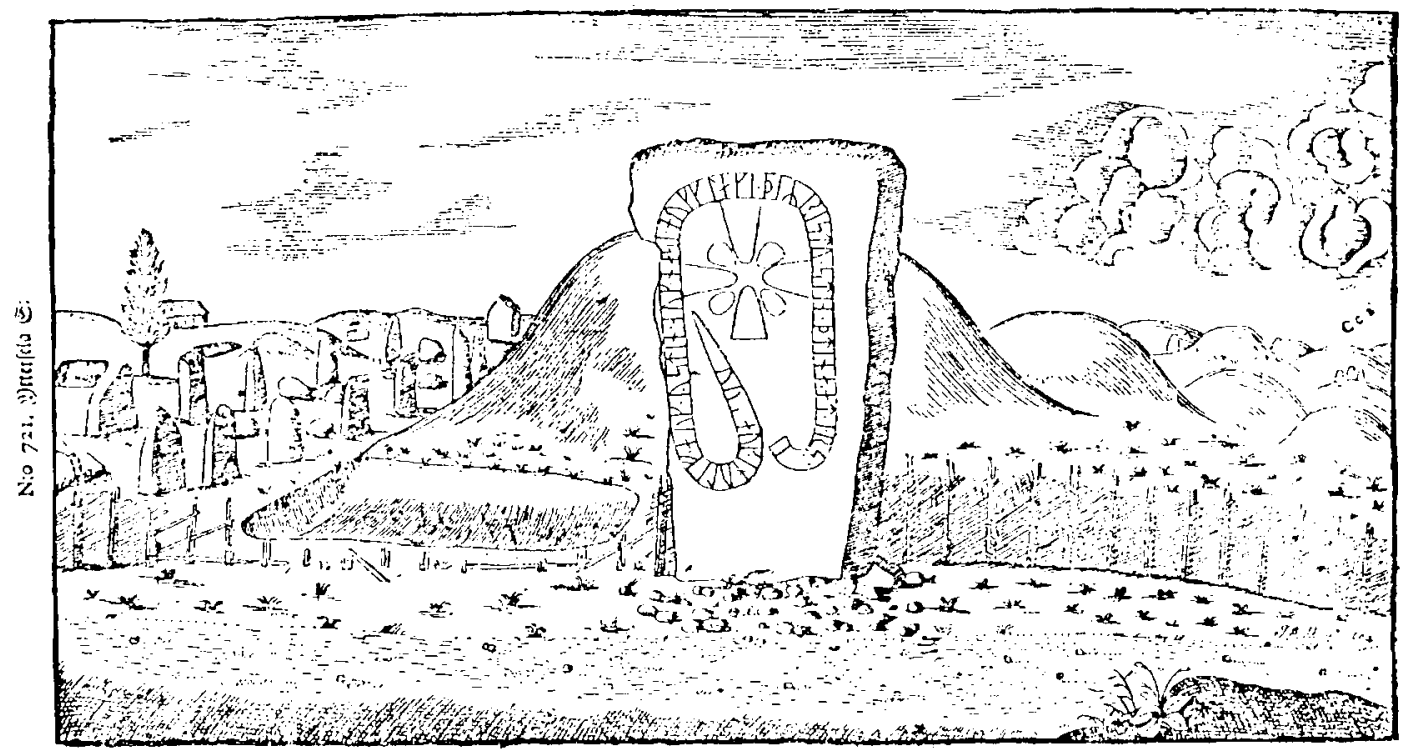

Fig. 4. The only way to enlighten the image of prehistory is to simulate the same fictive boundaries as prehistoric Man. Everything else is darkness! 
the reason why we have to understand each other. As Wittgenstein (1953) claims, a "private language" is not possible.

What we call reality or empirical facts is neither more nor less than broadly human collective fictions or theories. As Mats P. Malmer rightly maintains (1962:881), the delimited and fictive type is the foundation of archaeology. Science has to make empirical data of its theories. That is achieved by first setting up a boundary, then making this boundary accessible to the sensations, and finally accepting the boundary as a collective community of language. Archaeological empirical data can only be produced by simulating the basic concepts of ancient man. Malmer reminds us (1962:55) that an animal species cannot be revived but an ancient human concept can.

Any archaeological empirical fact that cannot be assigned to the intentions of ancient man is anachronistic. The most important source material in archaeology is living man. A systems theory that primarily proceeds from laws of nature or ecosystems is rather static Aristotelean concept realism. If we want to create an archaeological connexion we have to search for the most simple from a human point of view (Malmer 1962:879). Previously it was claimed that all sciences are of necessity interconnected, and that all knowledge emanates from the fundamental concepts of continuum and boundary. This means, of course, that the united science can be apprehended as a system of intertwined hierarchies of concepts. As producers of a total world classification we should nevertheless remain pure and faithful Aristoteleans.

What we really need is an evolved systems theory. The hitherto existing "scientific" systems theory has been based on faulty premisses, but in spite of this, all knowledge can be described by systems theory. Ryle might have said that it would be a category mistake to exclude systems theory since it is rather a general language than a separate science. The ultimate foundation of knowledge and the human connexion consist of language cri- tique. It is through systems theory as language that our connexion should be described. In any case we have to characterise the content of the human connexion.

\section{WHAT DOES THE HUMAN CONNEXION CONSIST OF?}

If we compare man with animals, what do we see? The similarities in bodily constitution are innumerable; mechanical functions, sense organs and metabolism are same. In most respects the constitutional capacity of animals is actually much greater than that of humans. A dog can run much faster; it has much warmer fur; it can bite better, etc. Then we come to the dissimilarities, man being flexible enough to "improve" his weak physical constitution. By means of artificial organs man can surpass the physical capacity of almost any animal.

What makes man more advanced or effective than animals is what archaeologists call "artifacts". The term artifact is doubtlessly very useful and practical, but it has some restrictions since it does not say anything about why artifacts exist and have a characteristic appearance.

Aristotle says in De Anima that the hand is the tool of tools, and that the mind is the form of forms. Emerson (Works, vol.7:151ff) perfects this idea, and says that all tools and machines on earth are extensions of the limbs and senses of man. As Emerson maintains, we can understand the limits of human artificial tools by the concept extension, "All the tools and engines on earth are only extensions of its limbs and senses. One definition of man is 'an intelligence served by organs" (Works, vol.7:151).

The human connexion is primarily characterised by the relationship between the "naked" man and his extensions. Emerson says that we expand by means of our extensions. Muscles are improved mechanically, the skin is extended to fit any climate and the eyes and the ears encompass the whole world with the aid of electricity. There seems to be no limit to 
such processes; art and power "will make day out of night, time out of space, and space out of time" (Works, vol.7:155).

Nonetheless, this expansion of the bodily functions is not, of course, always favourable. Edward Hall reminds us that "The evolution of weapons begins with the teeth and the fist and ends with the atom bomb" (1959, quotation after Mc Luhan 1962). It is not just increased effectivity that can be disastrous, but the fact that these extensions effect their user. When man integrates with machines he becomes a machine himself, and he is transformed into inert matter. Emerson shows us clearly how man in a society with divided human labour becomes a thing, or many things, "The priest becomes a form; the attorney a statute-book; the mechanic a machine, the sailor a rope of the ship" (Works, vol.1:85). In

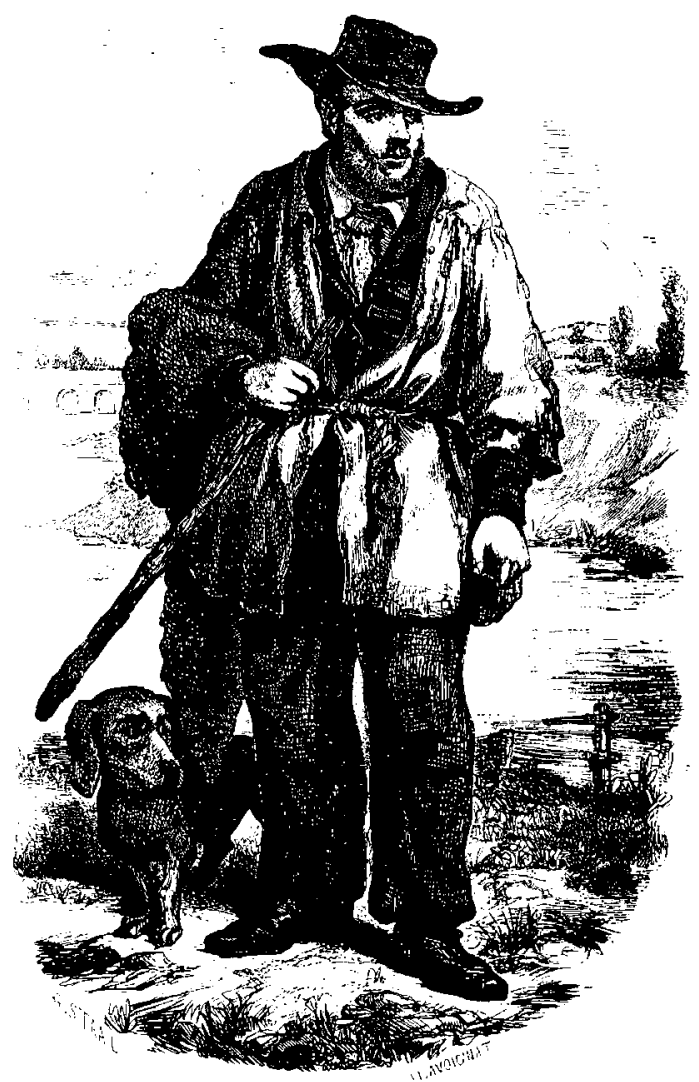

Fig. 5. Man reinforces his physical and mental capabilities with extensions. archaeology the idea of human extensions has been promoted by Gordon V. Childe (1942).

It is easy to understand that many things can be apprehended as extensions because they resemble bodily functions. A knife edge resembles our blunt teeth or nails; a cap resembles our hair and a stick resembles our arms or legs. We can call these analogous extensions, and some of them can even be utilised by animals.

Most of our extensions do not resemble the original bodily functions. Letters, for instance, do not resemble our memory or utterances; roads do not resemble our feet or legs, a castle does not resemble an authoritarian personality. These represent a kind of $a b$ stract extension, the functions of which are completely incomprehensible for both animals and uneducated humans. Nowadays it is popular to believe that the symbols in user manuals or on signposts are universally understandable, but in reality they are not. A measure of how tremendously abstract most extensions are is provided by the fact that it has taken man hundreds of thousands of years to evolve them.

Objectively speaking, extensions are something separate and accessory, but in the subjective view of man himself there is no boundary between man and his extensions, especially not when they are in operative use. $\mathrm{Ni}$ etzsche maintains that the ego of man has no fixed limit. Men are fond of underlining "the beauty of their children, their clothes, their dog, their physician, their town to their own credit and only stop short of saying 'all this am I'" (1881:151).

Our extensions include our most subjective feelings because they are an integrated part of ourselves. To confirm my extensions is kindness. To expand my extensions is friendship. To question my extensions is an insult. You may hit me, but if you shatter my most valued extensions, such as my family, music, poetry, fatherland, religion or indeed "fundamental concepts", you will shatter my innermost feelings. In a certain sense we grow when our extensions expand; conversely we 
shrink when we lose them. Gifts extend, punishments reduce. In Greek mythology we remember a staggering expression of this principle when the revengeful King Creon of Thebes lost his extensions that consisted of his family, and subsequently "lived like a tree with the branches cut off".

From a subjective point of view humaneness is something very continuous and transcending, from our own body to the environment. The dynamic intentions of man operate within a logical connexion. Intentions are always directed towards the environment and more or less inert extensions. Activity towards the inert is what Sartre (1960) calls praxis.

Reality dissolves. Our extensions dissolve. Thoughts and pictures on our retina dissolve very fast, spoken words slower, and the written word even slower. Extensions of stone, bronze or iron dissolve very slowly. Consequently, the human connexion does not only, of course, consist of dynamic man and the inert thing-world of extensions. Merleau-Ponty maintains that the problem is much greater:

"The question is to know whether, as Sartre says, there are only men and things or whether there is also the interworld, which we call history, symbolism, truth-to-bemade. If one sticks to the dichotomy, men, as the place where all meaning arises, are condemned to an incredible tension." (1955:200).

The continuous in the human connexion may be characterised as the fact that man's static inheritance of senses and limbs is "glued" by nerves and tissue, and that his dynamic inheritance of extensions is in its turn "glued" by what Merleau-Ponty calls the interworld.

\section{HOW ARE THE EXTENSIONS OF MAN TO BE APPREHENDED?}

The sciences of archaeology and history are restricted to the inert thing-world, naturally because the original connexions between man and things are lost. Nietzsche says (1881:156) that we will never know what actually happened, but only what caused consistent effects. How can we then acquire knowledge about things, and what do we want to know? A prerequisite then, as has been pointed out earlier, is that everything human is consistently logical.

The objection may be raised that there seems to be much in the human state that is not logical, but this, as Kierkegaard (1846) says, represents an objective viewpoint in the sense that no attention is paid to how the object acquires its meaning. In this case no attempt should be made to study history. It is necessary to consider human actions on the basis of what they are intended to be. In Kierkegaard's terms, the truth is in the subjective, i.e. the subjective of the studied man, not of ourselves. The rule for the archaeologist or the historian must be: science becomes objective if the scientist is subjective!

It might seem discouraging that no empirical data exist which are significant in "themselves". If the contrary was true, the very question would not have arisen. Hence it may be feared that archaeology cannot possibly be more than mere idealism and a collection of self-projected fantasies. This is probably why so many have felt secure with some kind of "sound empirical facts" but, just as fictionalism saves us from concept realism, the practical intentions of man save us from free fantasy. If we presuppose that all humans, now and in the past, are bound to transfer their fictions into inert matter by means of their practical actions, we will have something to build science on, i.e. an empirical source material.

Intentions are only possible in a world of boundaries, similarities and dissimilarities, and all these things are fictive. Examples of common fictions are thing, surface, volume, power, number, relation, cause, motion, purpose, freedom, justice, ethics, etc. We must apprehend reality through mediums of different kinds. Earlier we rejected the concept of the thing as reality in its own right. Thus we can define the thing as "the sum total of its effects, synthetically united by a concept, an 
image" (Nietzsche 1901:296). Reality does not determine which fictions man ought to use, but experience shows us which fictions are more or less practical. In a scientific context we can say that the empirical fact is a product composed of fictions, and theory is a set of fictions for identifying empirical data.

Archaeological science ought to generate knowledge about antiquity, or rather the people of antiquity, and produce knowledge about the present. In the past there were people, an environment and the things people made in this environment. Today we have fragments of all this. Nietzsche maintains that "The world seems logical to us because we have made it logical" (1901:283). Thus, when man creates something he makes the corresponding part of reality logical. When we without hesitation identify a stone axe as an artifact, it is because we, in a way that remains to be understood, actually occupy a viewpoint similar to that of ancient man. What we are doing is considering the axe as a piece of intentional logic. Nietzsche is of the opinion that "We can comprehend only a world that we ourselves have made" (1901:272). Thus something in our world has to coincide with something in the world of ancient man.

Nietzsche advances the idea (1881:89) that to be able to understand another man we have to imitate his feelings. In archaeology we act in a similar manner; to collect empirical data we imitate the same boundaries as those of ancient man. We reconstruct boundaries in a way that remains to be understood. The empirical facts of archaeology are always made of matter and they can be measured, but it is not the matter in "itself" that is the object of the science but the identification of the intentions of ancient man. In the inert matter some of the fictions of ancient man coincide with our own; this is exactly what we call the empirical data of archaeology. Emerson is right when he states that:

"All history becomes subjective; in other words there is properly no history, only biography. Every mind must know the whole lesson for itself - must go over the whole ground. What it does not see, what it does not live, it will not know" (Works, vol.2:15).

The knowledge about ancient man we want to collect is of necessity partly steered by his own original intentions. In this sense, it is not of course meaningful to say that his intention was to make a stone axe of feldspar and leucit, but if we use these fictions, we can with some certainty say that the ancient man intended to make the axe of what we now call stained porphyry. And what did ancient man know about gravity, amino acids or oscillations of molecules? However, in a manner that remains to be understood, we assume that his purpose was to hit the prey with the arrow and then satisfy his hunger and become warm. That we use other words for the same thing is of no importance, just as it is irrelevant that the Chinese use yet other words. The task of archaeology is not to identify the original words; that would certainly be to labour in vain. It is instead the boundaries of the original concepts that are to be identified. Emerson rightly maintains that the possibility of interpretation lies in the identity of the observer with the observed, and that "Every scripture is to be interpreted by the same spirit that gave it forth - is the fundamental law of criticism" (Works, vol. 1:40).

Of course intentionally made everyday objects are not the only things of archaeological interest. Phenomena such as fire, air, earth and water are also interesting. However, this does not change anything, since we may confidently assume that ancient man actually had concepts for these things, and that his boundaries for these concepts were almost the same as our own. We take for granted, as Kant would say, that it is within the physical constitution of man to separate earth and water, time and space, cause and effect, we and they, etc. That is a set of theories about man that remain to be understood! Whether ancient man had any intentions concerning what we now call red slate, hazel nuts or beavers can only be 
judged if we with our fictions and theories find some similarities and dissimilarities.

The phenomena that were not included in the fictions and intentions of ancient man cannot be used in any archaeological conclusions. In our age we can with our fictions generate a huge body of knowledge that never affected the actions of anyone before us. The fact that air contains nitrogen, that the stars are the same as our sun or that our flesh is made up of separate cells is all knowledge that is by no means relevant in an archaeological context. Is it not then a contradiction to endeavour, as Malmer says, to acquire all knowledge? Not at all, as long as we mean all knowledge about the intentions of ancient man. This is a most important distinction.

Look at something deposited by man, an inert extension of any kind. When we want to know all about this thing, it might be practical to talk about extensions that are conscious, subconscious and unconscious. We can look at a runestone, for instance. The writer of runes probably chose the site, the kind of stone, the type of runes and decoration very consciously. Subconsciously he might have chosen some common and popular elements of decor or colour. Unconsciously he probably used some local forms of words, and unconsciously he left a small cultural layer of stone chips and colour pigments.

Even if we are looking for ancient intentions, we can very well use anachronistic boundaries and concepts to reach the ancient intentions. Thus it may be necessary to use modern natural sciences to indirectly identify ancient intentions. If, for instance, some "iron oxide" is found on a runestone, we know that this is a concept that was completely unfamiliar to ancient man. However, if we imitate ancient man in a fictive manner, we may draw the conclusion that his purpose was to apply red paint to the runestone; we assume of course that the concept "redness" is non-anachronistic.

Desired knowledge about ancient things is never-ending. One can measure the angles and chemical composition of an object in an unlimited number of ways. When we document something that we consider to be empirical data, we have to make a selection and look at everything as if it was originally intentional, conscious or not. Empirical facts are forgotten theories.

\section{HOW CAN EXTENSIONS BE UNDERSTOOD AND EXPLAINED?}

To pinpoint some probable ancient intentions in a body of archaeological or historical material is not the same as presenting an explanation or understanding. This must be analysed. A human extension can be seen as a continuum with a finite number of attributed boundaries. The drawing of a new boundary generates a new continuum with new effects. We can, for instance, return to our runestone, and say that, as a "standing stone", it is a continuum within a "wide" boundary. Within this general boundary we can distinguish between stones with and stones without carved runes. A standing stone with runes can be considered a new continuum, in which we can, for instance, differentiate between stones with and without cross ornament. In this manner we draw "narrower" boundaries.

In many cases the boundaries we draw become general or narrow depending on where we begin our classification. From a scientific point of view, an attempt should be made to state and motivate everything that could possibly be considered as original intentions. The important thing is not the setting up of a more or less comprehensive boundary but that the boundary as such can be motivated.

Understanding can be defined as the identification of a "frame" between a set of wide, general and narrow, specialised boundaries. Our runestone, for instance, can in general terms be understood as a "cenotaph" for a "seafarer to England". Our understanding will become deeper and more complete as the number of pinpointed original boundaries rises. Understanding will also become deeper if we can show what might have been conscious or unconscious. 
Explanation can be defined as the identification of alloriginal intentions or boundaries. In this case it is not necessary to use the same words as those of ancient man, i.e. explanation is perfectly possible without knowledge of the spoken ancient language.

The general conclusion is that all human extensions can be understood, and that understanding always consists of a "frame-understanding". In principle every intention can also be explained. One further conclusion is that man as such can be understood since he can be placed within a frame understanding, but, if we maintain that man as such fulfils no purpose, he can never ever, as Nietzsche claims, be explained. Man can be understood but never explained.

\section{HOW CAN WE CREATE AN ARCHAEOLOGICAL CONNEXION?}

Above it was stated that during classical antiquity and the Middle Ages there was an ideal of scientific unity. A medieval scholar was expected to understand every aspect of reality in the light of the same philosophical prerequisites. Unfortunately this view has been lost to a great extent, not least in the twentieth century. If we want to re-establish the ideal of the united science, it might be beneficial to investigate the methods of some older scholars and historians. For instance, we can examine the questionable sixteenth-century Swedish historian, Johannes Magnus. Today nobody will deny that his version of history (1554) is pure fantasy. Nevertheless, his version of history is very interesting from a methodological point of view.

Johannes' version of history is very clear and straightforward; it could be said to include a most distinct frame-understanding. His most general or widest boundaries consist of the every-day historical "knowledge" of his day, i.e. the historical version of the Old Testament with the fall of the first man and the rise of culture under Magog, the grandson of Noah. Then the frame of history is widened with a large number of sources from classical antiquity and the Middle Ages. The special or narrow boundaries within the historical frame become a corresponding antipole; things that we would call empirical facts, ancient documents, artefacts, ancient monuments and legends.

The frame-understanding is clearly accepted as given by Johannes Magnus, and his task consists of filling the interspace or a kind of historical interpolation. Since his frame-understanding was very clear, he could easily fill most of the interspace, very nearly reaching a historical explanation.

Today we cannot accept the general part of Johannes' historical frame, even though we might use much of his special part. Still we must accept that both extreme parts of the frame are equally necessary. A major difference between him and us is that our general part is implicit and not described in so many words, but if no general boundaries exist, what we call empirical data cannot possibly be delimited, let alone placed in a meaningful context. Our task in this connexion is to make clear the importance of the frame-understanding, and to demonstrate how modern and acceptable general boundaries can be found in the frame.

\section{HOW IS ARCHAEOLOGY DEFINED IN THE UNITED SCIENCE?}

The viewpoint of the united science presupposes that all knowledge is of the same origin. The most general consists of the assumption that the structure of knowledge always comprises boundaries within a continuum. Every new boundary creates a new continuum (i.e. the same thing as Koestler's "holon"). Consequently we will obtain hierarchical structures that will always have at least one common boundary or connexion.

For instance, the boundary of a stone axe can be considered by both an archaeologist and a mineralogist, and both can place the same thing in different hierarchical structures. There is always at least one common boundary or connexion, such as "lithic mate- 
rial". Thus archaeology and mineralogy can be connected in a united science. In a corresponding manner absolutely every science can be connected in at least one and in reality in a countless number of ways. This may seem very simple, and it certainly is very simple, because this is how we have always acted.

Is it imaginable that any two sciences or two most simple pieces of everyday knowledge could lack such a connexion? No, because the physical constitution of man makes such connexions necessary. For instance, everyone must separate phenomena such as "thing", "motion", "cause", "food", etc. That we do not use the same words for the same phenomena is irrelevant. As Popper maintains, every language can in principle be translated into another, and a person can always learn a new language. We can add that this is possible because all languages have connecting boundaries.

To clarify the position of archaeology in the united science, some aspects have to be elucidated. What we need is an archaeological "raw material" and an accompanying context. The raw material consists of three things: first the fundamental structure of human cognition, second the "prototype" of all human extensions, i.e. the honoured reader of these words, and third a landscape filled with fragments of human extensions with original intentions.

In order to be able to point out the profiles of the archaeological connexion, we need first of all a language-critical foundation for all human conceptual similarities, i.e. logical necessities. We obtain this from the fictionalistic philosophy of boundaries, and the only fixed starting-point is the set of fundamental concepts, continuum and boundary. Everything that is called science relies on language criticism, and as Wittgenstein maintains, all philosophy is language criticism.

A prerequisite is that all men, now and in the future, have an unlimited number of intentions. In other words an unlimited number of boundaries can be drawn. Reality has no intentions or boundaries; they have to be attrib- uted by man, but that which was once intentional cannot be eradicated afterwards. Consequently there can only be one archaeological or historical understanding. In travesty of Ranke, it can be said that we want to know, not what really happened, but what was really intended. These intentions should be sought in the shape of boundaries rather than words. We can draw the following conclusion: the future is without un-freedom, the past is without freedom.

The totality of ancient intentions and boundaries is in principle limited, it being possible to identify only a small proportion of them, namely those that have become "frozen" in inert matter. Total explanations are impossible, of course, since we cannot identify all boundaries. Nevertheless, frame-understanding is quite possible.

Montaigne says that "Every man carries in himself the complete pattern of human nature" (1580, book 3, ch.2). What we need then are the psychological foundations of concepts for all human constitutional intentions from physiology and behaviourism. This is the more or less static inheritance of man. The necessity of behaviouristic studies in every scientific connexion cannot be emphasised enough. It would be a pseudo-humanist lie and a category mistake to say that science can develop without the study of behaviour. Nonetheless, behaviourism is derived from language criticism, and it cannot explain anything independently. On the foundations of psychology it is possible to reconstruct the originally intended boundaries.

When these prerequisites have been met, tacitly or not, the particular science can be defined, in this case archaeology. Then we can identify original intentions that can be measured in a conventional manner. The most simple and important convention is the pair of concepts similarity/dissimilarity. Thus we collect so-called empirical data that can be apprehended as human extensions or the $d y$ namic inheritance of man.

So far we might have succeeded in making archaeological empirical facts of our fictions. 


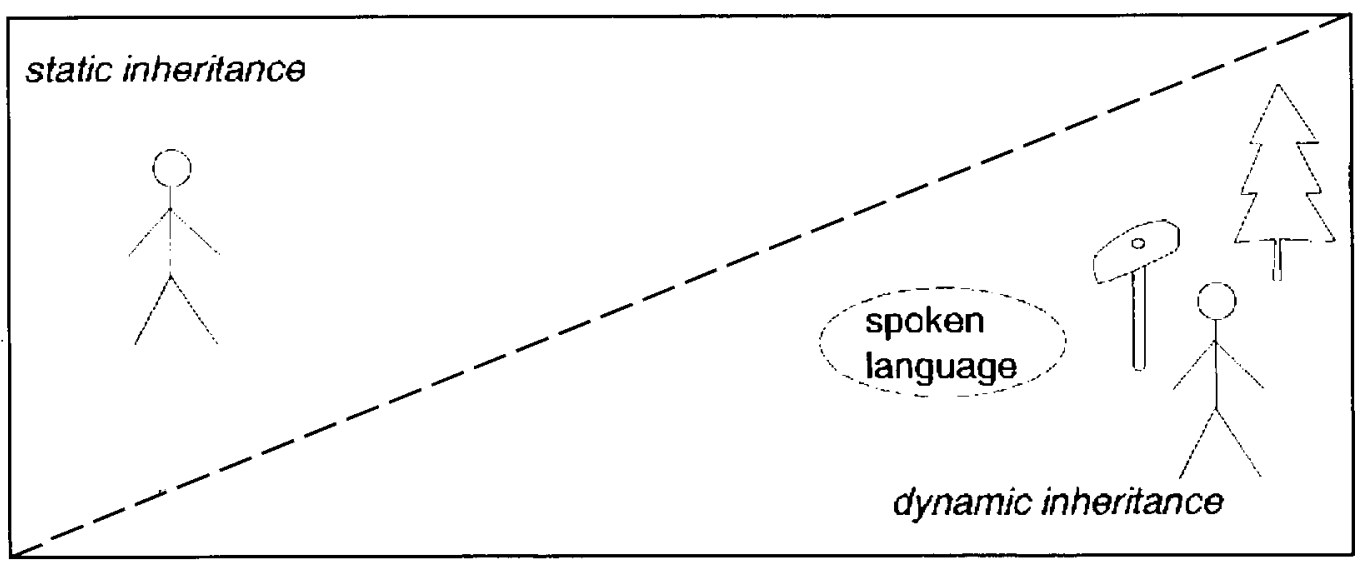

\section{human}

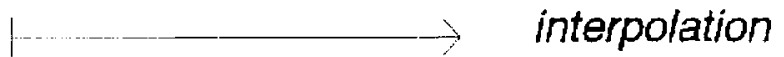

Fig. 6. Man is made of both a static and a dynamic inheritance. Archaeological and historical understanding is created through an interpolation between these starting-points.

However, this would be the same as having a long list of words, but no language. We still only have concepts for man and the world of things, and that is, as Merleau-Ponty maintains, insufficient. What we are lacking is an understanding of how man by means of the interworld is "glued" to his extensions; in other words, we lack history, sociology, etc. When we make an interpolation of the interworld, we will be able to show how man improves his physical constitution, what the extensions are intended for, how man is changed by them, why he changes them, how different extensions have been used by different people, etc.

\section{WHAT IS THE PURPOSE OF ARCHAEOLOGY IN THE UNITED SCIENCE?}

The aim of archaeology and history in the united science is to establish as far as possible which parts of man and his extensions are necessary and which are not, which are possible or impossible. Above we have defined the human context and how we can attain an archaeological and historical frame-understand- ing. However, this does not demonstrate the scientific benefit of delimiting effects. Thus our task is to present a frame-understanding of everything that can be described as operative effects, i.e. effects at this very moment. In this sense there is no boundary between scientific archaeology and history on the one hand and any everyday knowledge on the other.

Our heritage of words and things is of course both a resource and a burden. The same thing is valid for the sciences as such, both the human and the natural. Emerson repeatedly warns us against too much admiration of the past. And if history, as Nietzsche asserts (1874:95), always emphasises "the false, crude, inhuman, absurd, violent", these will be apprehended as ontological effects, and consequently be harmful to the present.

From this we can draw the conclusion that we have to distinguish between two different kinds of effects of the past. The first kind of effects are those that are operative even if we do not know about them, i.e. real a priori effects. These kinds of effects are within our physical constitution. The second kind of effects are those that become operative only when they are considered, i.e. unreal a poste- 
riori effects, such as those Nietzsche mentioned above. In archaeology and history we have seen a great number of a posteriori effects.

As an example of a priori effects the so called large-scale of society can be mentioned. If we experience the effects of this as a problem, they will of course remain a problem. In order to assess the "nature" of large scale, it is necessary to investigate former societies. If large scale has always involved harmful effects, then we can say that these effects are inherent in the grandness of scale.

Scientific archaeology and history have to steer between their Scyllae and Carybdis. They represent the historical version that only becomes a harmful burden for the present and the historical version that deliberately conceals historical knowledge. However, in the same way as the human language can grow into a greater community of language, archaeology and history in the united science can grow without any deliberate concealment. This is effected by confronting any potential ontological burden with eager demands for its opposite. Obviously this is why we have re- cently seen so much history of workers, women or the arts of peace. This does not mean that historical knowledge has to constantly expand, since a fictive total knowledge would lead to total paralysis. The ability to forget is, as Nietzsche maintains (1874:63), just as important as the ability to remember. In other words, the unhistorical is just as important as the historical.

We have seen how archaeology is possible at all. By setting out from what all humans have in common, we are able in a scientifically united manner to extend our senses fictively towards the past. Moreover, it is only when we can reduce scientific observations into everyday concepts that they are of any use. There is no need to create an archaeology in the united science since science has always been united, but we have to elucidate what remains to be understood. We ourselves, and the things we can apprehend, are the only material for our scientific tools. We ought to make tools as simple as possible. How are we and our extensions falling?

English revised by Jacqueline Taffinder.

\section{REFERENCES}

Austin, J.L. (1962). How to do things with words. Reprint, Oxford 1990 .

Ayer. A.J. (1936). Language, whth and logic. Reprint 1971. Harmondsworth.

Childe, G.V. (1942). What happened in history. Swedish translation, Människan skapar sig själv. Uppsala 1954.

Descartes, R. (1637). Discourse on method. English translation, Indianapolis 1988.

Emerson, R.W. (Manuscripts written 1836-1876). The works of Ralph Waldo Emerson. Volumes 1-12. Fireside edition. Boston and New York 1909.

Huizinga, J. 1945. Homo ludens. Swedish translation, Den lekande människan. Stockholm.

Hume. D. (1738). A treaty on human understanding. Swedish translation, Om det mänskliga förständet. Stockholm 1929.
Jensen, I. \& Vestergaard, F. 1979. Praxis och tröghet. Om Sartres bidrag till samhälsforrstaelse. Swedish translation, Göteborg.

Jones, W.H.S. (1931). Hippocrates and the fragments of Heracleitus. Vol. 4.. Loebclassical library. Reprint. Harvard 1979.

Jones, W.T. 1975. A history of Western Philosophy. The wentieth Century to Witgenstein and Sartre. 2nd ed. New York.

Kierkegaard, S. (1846). Concluding In-scientific postscript. English translation Reprint. Princeton 1968.

Koestler, A. (1978).Janus. Swedish translation. Göteborg 1989.

Kripke, S.A. 1980. Naming and necessiny. Oxford.

Lange. F.A. (1865). Materialismens historia. Swedish translation, revised and abridged. Stockholm 1913. 
Leibniz, G.W. (1695 \& 1705). Ett nytt system; Betraktelser över livsprinciperna. Den förutbestamda harmonien. Swedish transl., 1927.

Lübcke, P. e1. al. 1987. Vïr tids filosofi. Swedish translation. Stockholm.

Mc Luhan, M. (1962). The Gutenberg galary. London, Reprint 1967

- (1964). Media the extensions of man. Swedish translation, Media, mämniskans ubyggnader. Stockholm 1967.

Malmer, M.P. 1962. Jungneolithische studien. Lund.

- 1968. De kronologiska grundbegreppen. Fornväinen.

- 1984. Arkeologisk positivism. Fornvännen.

- 1988. Konstanter och variabler i det förhistoriska samhället. Fornvännen.

- 1990. Comments to D. Tangri: Science, hypothesis testing and prehistoric pictures. Rock Art Research. vol $7, \mathrm{nr} /$.

- 1991. Comments to R.A. Watson: What has the new archaeology accomplished. Current Anthropology. Vol. $32, n r .3$.

Merleau-Ponty, M. (1945). Phenomenology of perception. English translation, reprint. London 1970.

- (1955). Adventures of dialectic. English translation, Evanston 1973.

Montaigne, M. (1580). Essays. English translation 1958, reprint. Harmondsworth 1989.

Nietzsche, F. (1874). On the use and disadiantage of history for life. In: Untimely meditations. English translation. Cambridge 1988.

- (1881). Daybreak, Thoughts on the prejudices of morality. English translation. Cambridge 1987.

- (1882). The gav science. English translation. New York 1974
- (1886a). Beyond good and evil. Prelude to a history of the future. English translation. New York 1966.

- (1886b). Human all too human. A book for free spirits. English translation. Cambridge 1988.

- (1887). On the genealogy of morals. English translation. New York 1967

(1889). Twilight of the idols, or how to philosophize with a hammer. English translation. London 1990.

- (1901). The will to power. (Notes written 18831888, edited and posthumously published) English translation. New York 1988.

Pascal, B. (1637). Pensees. Swedish translation. Tankar. Uddevalla 1971

Quine, W.V.O. (1955). Two dogmas of empiricism. From a logical point of view. Cambridge. Mass. 1980.

Ricoeur, P. 1976. Interpretation theory. Forth Worth. Ryle, G. (1949). The concept of mind. Reprint, Middlesex 1990.

Sartre. J-P. (1943). Beeing and nothingness. English translation. Reprint, London 1972.

- (1958). Questions de métode. Swedish translation, Till frágan om metoden. Nytryck, Malmö 1984.

- (1960). Critique of dialectical reason. English translation. Reprint, London 1982.

Searle, J.R. (1969). Speech acts. An essay in the philosopy of language. Reprint. Cambridge 1989.

Vaihinger, H. 1918. Die philosophie des Als ob. 3te auflage, Leipzig.

Wittgenstein, L. (1953). Philosophical investigations. 2nd edition. 1958. 